\title{
Dampak Perubahan Iklim Terhadap Kejadian Demam berdarah di Jawa Barat
}

\author{
Ardini S Raksanagara ${ }^{1}$, Nita Arisanti², Fedri Rinawan ${ }^{3}$ \\ ${ }^{1}$ Departemen Ilmu Kesehatan Masyarakat Fakultas Kedokteran, Universitas Padjadjaran
}

\begin{abstract}
Abstrak
Lingkungan merupakan determinan kesehatan yang dapat memengaruhi kesehatan masyarakat selain faktor perilaku, pelayanan kesehatan dan genetik serta kependudukan. Pada saat ini telah terjadi perubahan lingkungan termasuk perubahan iklim global yang menjadi isu sangat penting. Perubahan iklim tersebut dipicu oleh terjadinya pemanasan global (global warming) dan efek rumah kaca (greenhouse effect). Perubahan iklim yang terjadi dapat berupa peningkatan suhu, perubahan kelembaban, peningkatan curah hujan yang menjadi faktor risiko terhadap derajat kesehatan masyarakat karena timbulnya penyakit menular yang ditularkan melalui udara, air dan vektor. Penyakit Demam Berdarah merupakan penyakit menular yang ditularkan melalui perantara vektor nyamuk dan erat kaitannya dengan perubahan iklim. Tempat perindukan nyamuk ini sangat dipengaruhi oleh ketinggian tempat (altitude), kemiringan lereng (slope) dan penggunaan lahan (land use), sedangkan unsur cuaca memengaruhi metabolisme, pertumbuhan, perkembangan dan populasi nyamuk tersebut. Curah hujan dengan penyinaran yang relatif panjang turut memengaruhi habitat perindukan nyamuk. Tujuan penelitian ini adalah untuk mengetahui keterkaitan perubahan iklim khususnya perubahan curah hujan dengan terjadinya demam berdarah di Jawa Barat pada tahun 2004 sampai dengan 2008. Desain penelitian ini adalah deskriptif, dengan mengumpulkan data sekunder mengenai perubahan curah hujan dan kejadian penyakit demam berdarah di Indonesia. Data curah hujan didapatkan dari BMKG sedangkan data kejadian demam berdarah didapatkan dari Dinas Kesehatan Provinsi Jawa Barat. Data curah hujan dan kejadian demam berdarah dipresentasikan dalam bentuk tabel yang digambarkan perubahan setiap bulannya selama 5 tahun yaitu 2004 sampai 2008. Dampak curah hujan terhadap kejadian demam berdarah dianalisis menggunakan linear regresi model. Dari penelitian ini dikatakan bahwa curah hujan berpengaruh terhadap kejadian demam berdarah, di mana curah hujan mempunyai nilai prediksi yang berhubungan dengan terjadinya demam berdarah. Walaupun demikian, terdapat perbedaan waktu (time lag) antara peningkatan curah hujan dan peningkatan kasus demam berdarah. Perubahan iklim berpengaruh terhadap kerentanan kesehatan, sehingga perubahan iklim ini harus dihadapi. Oleh karena itu, melindungi diri dari perubahan iklim dibagi atas upaya mitigasi (minimalisasi penyebab dan dampak) dan adaptasi (menanggulangi risiko kesehatan). Early warning system terhadap kejadian luar biasa DBD harus dilaksanakan di setiap daerah dengan memperhatikan kecenderungan perubahan faktor iklim. Selain itu diperlukan perbaikan lingkungan yang harus disertai dengan perubahan faktor lain seperti perilaku dan pelayanan kesehatan.
\end{abstract}

Kata kunci : Curah hujan, demam berdarah, perubahan iklim, penyakit tular vektor 


\title{
Impact of Climate Change to Incidents of Dengue in West Java
}

\begin{abstract}
An environmental determinants of health that can affect people's health in addition to behavioral factors, health services and genetic and demographic. In the event of environmental change, global climate change is becoming a very important issue. The climate change triggered by global warming and the greenhouse effect Climate change is happening can include increased temperature, humidity, rainfall increase the risk factor for the degree of public health because of the emergence of infectious diseases that are transmitted through the air, water and vectors. Dengue Fever is infectious disease transmitted through mosquito vectors intermediaries and closely related to climate change. Breeding places is strongly influenced by altitude the slope and land use, while the weather elements affecting metabolism, growth, development and the mosquito population. Precipitation with a relatively long exposure also affect mosquito-breeding habitat. The purpose of this study was to measure the relevance of climate change, especially changes in rainfall with occurrence of dengue fever in West Java.

The study design was descriptive. Secondary data was collected from Department of Meteorology, Climatology and Geophysics and Provincial Health Office. The data of rainfall and the incidence of dengue was presented using table to describe the changes of rainfall and the incidence in each month period of data collection (2004 - 2008). Based on the study, the rainfall affects the incidence of dengue, where rainfall has predictive value associated with the occurrence of dengue fever. However, there is a time difference (time lag) between the increase in precipitation and an increase in cases.

Climate change effect on health vulnerabilities, so that climate change must be faced. Therefore, the protection effort from climate change mitigation divided into minimization of the causes and effect and adaptation (tackling health risks). Early warning system for unusual occurrence of dengue should be carried out in each area by taking into account the tendency of changes in climatic factors. Also required environmental improvements must be accompanied by changes in other factors such as behavioral and health services.
\end{abstract}

Key words: Climate change, dengue, rainfall vector communicable disease

Korespondensi :

Dr. Ardini S. Raksanagara, dr., MPH

Departemen Ilmu Kesehatan Masyarakat Fakultas Kedokteran Unpad

Jl. Eijkman No. 38 Bandung

Mobile :0811237159

Email : araksanagara@yahoo.com 


\section{Pendahuluan}

Lingkungan adalah segala sesuatu yang berada di sekitar manusia serta pengaruh-pengaruh luar yang memengaruhi kehidupan dan perkembangan manusia. Lingkungan sekitar kehidupan manusia terbagi menjadi 3 kategori, yaitu lingkungan fisik, lingkungan biologis dan lingkungan sosial. Adapun yang dimaksud lingkungan biologis adalah segala bentuk kehidupan yang berada di sekitar manusia seperti 1) binatang (fauna); 2) tumbuh-tumbuhan (flora); 3) mikroorganisme. ${ }^{1,2}$

Pada saat ini secara global dunia mengalami masalah perubahan iklim. Adapun dampak perubahan iklim ini sangat kompleks mencakup berbagai aspek kehidupan manusia. Dampak perubahan iklim yang sangat dirasakan adalah terjadinya peningkatan suhu, peningkatan curah hujan dan terjadinya perubahan iklim ekstrim. 3 Perubahan iklim ini akan berpengaruh terhadap kesehatan manusia baik secara langsung maupun secara tidak langsung. Perubahan iklim secara langsung akan merugikan kesehatan manusia terutama yang berhubungan dengan kejadian penyakit, terutama penyakit yang ditularkan oleh vektor seperti demam berdarah. Efek perubahan iklim yang tidak langsung terhadap kesehatan manusia adalah melalui penyakit yang ditularkan serangga dan hewan pengerat-menular (misalnya, malaria, demam berdarah, virus demam west nile, penyakit lyme dan hantavirus pulmonary syndrome); meningkat asap dan polusi udara; penyakit yang ditularkan melalui air dan makanan yang berhubungan dengan penyakit (misalnya, giardiasis, infeksi e. coli, dan keracunan kerang); radiasi ultra violet kuat yang dapat menyebabkan kanker kulit dan katarak. ${ }^{5}$

Demam berdarah merupakan penyakit yang ditularkan oleh vektor nyamuk. Perkembangan vektor penyakit dapat dipengaruhi terjadinya perubahan iklim melalui berbagai cara 1) unsur cuaca memengaruhi metabolisme, pertumbuhan, perkembangan dan populasi nyamuk tersebut; 2) curahhujandenganpenyinaranyang relatifpanjang turut memengaruhi habitat perindukan nyamuk.

Berdasarkan data WHO pada tahun 2003, dilaporkan bahwa terjadinya perubahan iklim berperan dalam terjadinya penyakit diare sebesar $2,4 \%$ dan penyakit malaria sebesar $2 \%$. Pada tahun 2000, WHO menduga bahwa sekitar 150.000 kematian disebabkan oleh perubahan iklim. 3,5

Demam berdarah merupakan salah satu penyakit yang sensitif terhadap perubahan cuaca. Diperkirakan penyakit ini akan menonjol pada tahun 2080, sekitar 6 miliar orang akan berisiko tertular demam berdarah sebagai konsekuensi dari perubahan iklim, dibandingkan dengan 3-5 miliar orang jika iklim tetap tidak berubah. Dapat dikatakan bahwa pemanasan global berperan terhadap penyakit tular vektor. ${ }^{5}$ Dari uraian diatas maka penelitian ini berujuan untuk mengetahui gambaran keterkaitan perubahan iklim khususnya perubahan curah hujan dengan terjadinya demam berdarah di Jawa Barat pada tahun.

\section{Metode}

Desain penelitian ini adalah deskriptif, dengan mengumpulkan data sekunder mengenai perubahan curah hujan dan kejadian penyakit demam berdarah di Indonesia. Data curah hujan didapatkan dari BMKG sedangkan data kejadian demam berdarah didapatkan dari Dinas Kesehatan Provinsi Jawa Barat. Data curah hujan dan kejadian demam berdarah dipresentasikan dalam bentuk tabel yang digambarkan perubahan setiap bulannya selama 5 tahun yaitu 2004 sampai 2008. Variabel tergantung adalah terjadinya kejadian demam berdarah, dan yang menjadi variabel bebasnya adalah perubahan iklim yang digambarkan oleh curah hujan. Dampak curah hujan terhadap kejadian demam berdarah dianalisis menggunakan linear regresi model.

\section{Hasil}

Berdasarkan penelitian ini didapatkan data perubahan iklim yaitu curah hujan serta kejadian demam berdarah selama 5 tahun (2004 - 2008) di Jawa Barat. Dari data yang didapatkan kemudian diolah dengan bantuan komputer untuk menggambarkan pola curah hujan dan kejadian demam berdarah.

Kejadian demam berdarah di Jawa Barat selama 5 tahun mengalami perubahan yang berfluktuasi dan angkanya terus meningkat. Demikian juga dengan gambaran pola curah hujan yang mengalami fluktuasi dan terus meningkat seperti digambarkan pada gambar 1 .

Dari gambar tersebut dapat dilihat kecenderungan kenaikan curah hujan yang disertai dengan kenaikan kejadian demam berdarah. Walaupun demikian, terdapat perbedaan waktu (time lag) antara peningkatan curah hujan dan peningkatan kasus. Untuk mengetahui pengaruh curah hujan terhadap kejadian demam berdarah, analisis yang digunakan adalah linear regresi logistic dan didapatkan persamaannya pada setaiap tahun seperti pada tabel 1 .

Pada tahun 2004 dan 2005 dapat dilihat bahwa curah hujan memiliki pengaruh yang cukup besar terhadap kejadian demam berdarah 


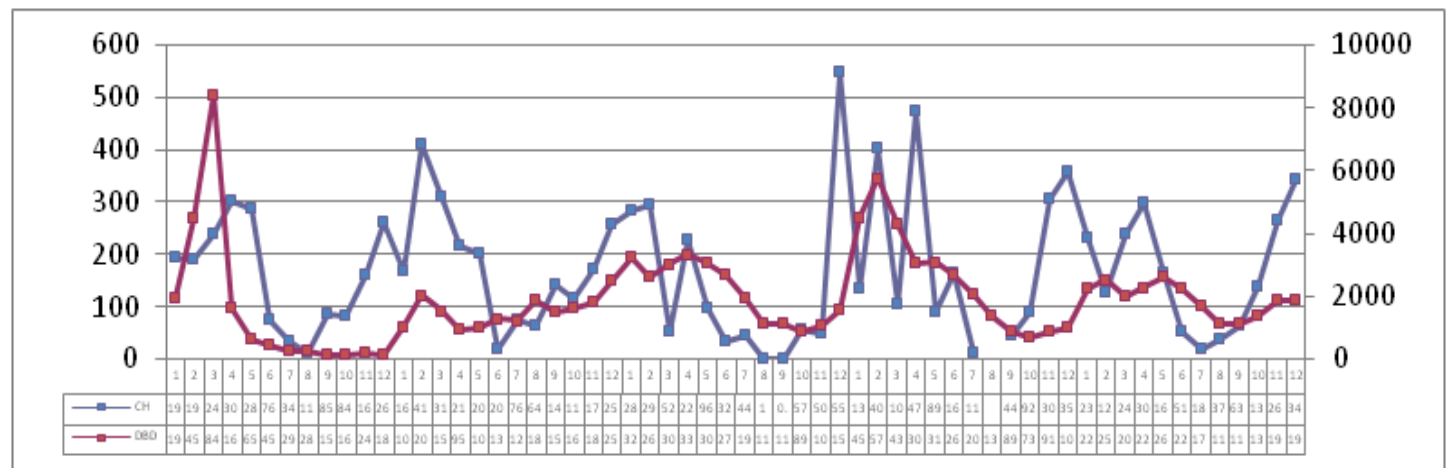

Gambar 1. Pola Perubahan Curah Hujan dan Kejadian Demam Berdarah di Jawa Barat, Tahun 2004 - 2008

Tabel 1. Besarnya Pengaruh Curah Hujan Terhadap Kejadian Demam Berdarah pada Tahun $2004-2007$

\begin{tabular}{cccc}
\hline Tahun & $\mathbf{B 0}$ & $\mathbf{B 3}(\mathbf{C H})$ & r2 \\
\hline 2004 & 1459 & 0,8 & 0,21 \\
2005 & 536,9 & 0,8 & 0,34 \\
2006 & $-486,9$ & $-0,2$ & 0,66 \\
2007 & 1100 & 0,03 & 0,27 \\
\hline
\end{tabular}

\section{Pembahasan}

Terjadinya suatu penyakit menurut Henrik L Blum adalah sebagai akibat interaksi antara lingkungan, perilaku, pelayanan kesehatan dan keturunan, sedangkan berdasarkan teori segitiga epidemiologi terjadinya suatu penyakit karena terdapatnya interaksi antara pejamu/host, agen penyakit dan lingkungan. 2

Cuaca dan iklim berpengaruh terhadap patogenesis berbagai penyakit yang berbeda dan dengan cara berbeda satu sama lain pula. Salah satu pengaruh perubahan iklim adalah terhadap potensi peningkatan kejadian timbulnya penyakit yang ditularkan oleh nyamuk seperti Malaria, Radang Otak akibat West Nile Virus, Filariasis, Japanese Encephalitis, dan Demam Berdarah. Perubahan suhu, kelembaban dan kecepatan angin dapat meningkatkan populasi, memperpanjang umur dan memperluas penyebaran vektor sehingga berdampak terhadap peningkatan kasus penyakit menular seperti: malaria, dengue fever, schistosomiasis, filariasis dan pes. ${ }^{6}$

Pada kejadian demam berdarah, meningkatnya penyebaran penyakit dapat disebabkan oleh meningkatnya jumlah vektor sebagai perantara penyebaran penyakit. Curah hujan yang tinggi menimbulkan genangan-genangan air yang merupakan tempat perindukan yang nyaman bagi nyamuk penyebar penyakit. Selain itu, tempat perindukan nyamuk ini sangat dipengaruhi oleh ketinggian tempat (altitude), kemiringan lereng (slope) dan penggunaan lahan (Land Use), sedangkan unsur cuaca memengaruhi metabolisme, pertumbuhan, perkembangan dan populasi nyamuk tersebut. Curah hujan dengan penyinaran yang relatif panjang turut memengaruhi habitat perindukan nyamuk. ${ }^{7}$

Penelitian tentang perubahan iklim dan penyebaran virus dengue menemukan bahwa ratarata suhu dan curah hujan mempunyai pengaruh yang bermakna dengankejadian demam berdarah. ${ }^{8}$

Hasil penelitian ini memperkuat penelitian sebelumya yang menunjukkan bahwa curah hujan merupakan salah satu prediktor utama penularan demam berdarah. Karena curah hujan yang tinggi akan meningkatkan kelembaban relatif sehingga memperpanjang umur nyamuk dewasa. Peningkatan curah hujan dapat meningkatkan habitat dan populasi larva dan juga menciptakan habitat baru untuk nyamuk dewasa. ${ }^{10-11}$ Tingginya kejadian penyakit Demam berdarah di Jawa Barat dan tingginya curah hujan disebabkan oleh faktor geografis Jawa Barat yang relatif lebih tinggi dibandingkan propinsi lainnya di pulau Jawa.

Keterbatasan penelitian yang ditemukan adalah beberapa data tidak lengkap untuk kepentingan analisis. 
Dari hasil penelitian dapat disimpulkan bahwa perubahan iklim, yaitu terjadinya perubahan curah hujan berdampak pada kenaikan kejadian demam beradarah. Oleh karena itu, untuk melindungi masyarakat dari dampak perubahan iklim terhadap kejadian demam berdarah ini, diperlukan berbagai upaya seperti upaya mitigasi (minimalisasi penyebab dan dampak) dan adaptasi (menanggulangi risiko kesehatan). Early warning system terhadap kejadian luar biasa DBD harus dilaksanakan di setiap daerah dengan memperhatikan kecenderungan perubahan faktor iklim. Selain itu diperlukan perbaikan lingkungan yang harus disertai dengan perubahan faktor lain seperti perilaku dan pelayanan kesehatan.

\section{Daftar Pustaka}

1. Samet, JM. Adapting to Climate Change - Public Health. Adaptation-An Initiative of the Climate Policy Program. RFF. 2009.

2. Detels R, Breslow L, editors. Oxford textbook of public health. 4th ed. New York: Oxford University Press; 2002.

3. Bappenas. Indonesia Climate Change Sectoral Roadmap. 2010.

4. Departemen Kesehatan RI. Profil Kesehatan Indonesia 2008. Jakarta. 2009.
5. World Health Organisation. Climate change and human health: Risks and responses. 2003 (online at: http:/ /www. euro.who.int/) (Accessed April 2007)

6. Paul R. Epstein and Evan Mills, Climate Change Futures. Health, Ecological and Economic Dimensions. The Center for Health and the Global Environment Harvard Medical School. 2006.

7. Bertollini, Roberto. Global Perspectives on Climate Change and Health. Makalah disampaikan pada National Workshop on Human Health and Climate Change, Jakarta, 22-23 Report of the Regional Study on Global Environment Issues: Country Study of Indonesia November. 2007.

8. Wongkoon $\mathrm{S}$, Jaroensutasinee $\mathrm{M}$, Jaroensutasinee $\mathrm{K}$. Climatic variability and dengue virus transmission in Chiang Rai, Thailand. Biomedica. 2011 (27):5-13.

9. Intergovernmental Panel on Climate Change. Climate Change 2007: Impacts, Adaptation and Vulnerability. IPCC . Geneva. 2007.

10. Corwin AL, et al. Epidemic dengue transmission in southern Sumatra, Indonesia. TransRSocTropMedHyg.2001;95(3):257-65.

11. Karim M.N, Munshi S.U, Anwar N, Alam MS. Climatic factors influencing dengue cases in Dhaka city: a model for dengue prediction. Indian J Med Res 136. 2012:32-39. 